\title{
Correlation between intake and ingestive behavior of pasture-grazed heifers ${ }^{1}$
}

\section{Correlação entre consumo e comportamento ingestivo de novilhas suplementadas a pasto}

\author{
Hermógenes Almeida Santana Junior ${ }^{2 *}$; Robério Rodrigues Silva ${ }^{3}$; \\ Gleidson Giordano Pinto Carvalho ; Fabiano Ferreira Silva ${ }^{3,6}$; Geraldo Trindade Junior ${ }^{3}$; \\ Alyson Andrade Pinheiro"; Eli Santana Oliveira Rodrigues ${ }^{5}$; George Abreu Filho ${ }^{5}$; \\ Elizangela Oliveira Cardoso Santana ${ }^{5}$; Fabricio Bacelar Lima Mendes ${ }^{5}$
}

\begin{abstract}
The objective of this study was to evaluate the correlation between intake and ingestive behavior of crossbred heifers in grazing tropical. The experiment was conducted on the Princesa do Mateiro Farm, in the city of Ribeirão do Largo, Bahia. A total of 20 heifers with genetic makeup 5/8 dairy Guzerá and 3/8 Holstein, average age of 18 months and body weight of $187 \pm 13.1 \mathrm{~kg}$ have been used. The experiment lasted 224 days and involved animals raised in a rotational grazing system with Brachiaria brizantha cv. Marandú. Grazing time was not correlated with any of the variables associated with intake. Rumination time showed positive correlations with the intake of forage dry matter (DMIF) and neutral detergent fiber (NDFI). Variables associated with the time spent on feeding at the trough, overall feeding and total chewing were not correlated with intake $(\mathrm{P}>0.05)$. There have been positive correlations between the number of grazing periods (NGP) and rumination periods (NRP) and total DM intake (TDMI), organic matter (OMI), forage (DMIF), neutral detergent fiber (NDFI), total carbohydrates (TCHI) and ether extract (EEI). Crude protein intake (CPI) was positively correlated with NGP and NRP. The mouthful rate was positively correlated with TDMI, OMI, DMIF, NDFI, TCHI, EEI and CPI. Average time per swallow was negatively correlated with TDMI, OMI, NDFI, TCHI and EEI. Positive correlations have been observed between the number of mouthfuls per day and TDMI, OMI, DMIF, NDFI, TCHI, EEI. The number of chews per bolus showed negative correlations with DMIS and CPI. The time per cake ruminated has correlated negatively with the intake of crude protein. The number of chews per bolus showed positive correlations with the intakes of dry matter and neutral detergent fiber. The number of boli per day showed positive correlations with DMIF and TCHI. The time spent on chewing showed no significant correlation with intake. In conflict with the national and international literature, the grazing time was not correlated with intake by grass-fed crossbred heifers. The number of activities, the time spent on them and the mouthful rate where shown to be highly associated with the intake variables and can therefore arrange equations to predict intake through the analysis of feeding behavior. The number
\end{abstract}

\footnotetext{
${ }^{1}$ Project funded by Banco do Nordeste do Brasil, BNB.

${ }^{2}$ Teacher of Universidade Estadual do Piaú, UESPI, Av. Joaquina Nogueira, s/n, Aeroporto, Corrente, PI, Brazil. E-mail: hsantanajunior@hotmail.com

${ }^{3}$ Teachers of Universidade Estadual do Sudoeste da Bahia, UESB, Itapetinga, BA, Brazil. E-mail: rrsilva@cnpq.br; ffsilva@cnpq. br; geraldouesb@hotmail.com

${ }^{4}$ Teachers of Universidade Federal da Bahia, UFBA, Salvador, BA, Brazil. E-mail: gleidsongiordano@hotmail.com; jagualyson@ bol.com.br

${ }^{5}$ Post graduate of Universidade Estadual do Sudoeste da Bahia, UESB, Itapetinga, BA, Brazil. E-mail: eli@hotmail.com; georgeabreu@hotmail.com; eocardoso@hotmail.com; fabricio.bacelar@hotmail.com

${ }^{6}$ Researcher the National Research Council, CNPq.

* Author for correspondence
} 
of mouthfuls performed each day contributes to the intake by pasture-grazed heifers.

Key words: Bovine, feeding, ingestion, mouthful

\section{Resumo}

Objetivou-se com este estudo, avaliar a correlação entre o consumo e comportamento ingestivo de novilhas mestiças em pastagem tropical. O experimento foi conduzido na Fazenda Princesa do Mateiro, na cidade de Ribeirão do Largo, Bahia. Foram utilizadas 20 bezerras com a composição genética de $5 / 8$ de Guzerá Leiteiro e 3/8 de Holandês, idade média de 18 meses e peso corporal de $187 \pm 13,1$ kg. O experimento durou 224 dias e os animais mantidos em sistema de pastejo rotacionado com Brachiaria brizantha cv. Marandú. O tempo de pastejo não correlacionou com nenhuma das variáveis associadas com a ingestão. $\mathrm{O}$ tempo de ruminação mostrou correlações positivas com a ingestão de matéria seca da forragem (CMSF) e fibra em detergente neutro (CFDN). Variáveis associadas ao tempo gasto em alimentação no cocho, alimentação em geral e mastigação total, não foram correlacionados com a ingestão $(\mathrm{P}>0,05)$. Houve correlação positiva entre o número de períodos de pastejo (NPP) e os períodos de ruminação (NPR) e consumo de MS total (CMST), matéria orgânica (CMO), forragem ( CMSF), fibra em detergente neutro (CFDN), carboidratos totais (CCHOT), extrato etéreo (CEE). O consumo de proteína bruta (CPB) foi positivamente correlacionado com NPP e NPR. A taxa de bocado foi positivamente correlacionada com CMST, CMO, CMSF, CFDN, CCHOT, CEE e CPB. O tempo médio por bolo ruminado foi negativamente correlacionada com CMST, CMO, CFDN, CHOT e CEE. Correlações positivas foram observadas entre o número de bocados por dia e CMST, CMO, CMSF, CFDN, CHOT e CEE. O número de mastigações por bolo mostraram correlações negativas com CMSS e CPB. O tempo por bolo ruminado foi negativamente correlacionada com a ingestão de proteína bruta. O número de mastigações por bolo mostrou correlações positivas com os consumos de matéria seca e fibra em detergente neutro. O número de bolos por dia mostraram correlações positivas com CMSF e CCHOT. O tempo de mastigação não mostrou correlação significativa com o consumo. Em conflito com a literatura nacional e internacional, o tempo de pastejo não foi correlacionada com a ingestão por novilhas mestiças em pastejo. O número de atividades, o tempo gasto e a taxa de bocado, tem demostrado ser altamente correlacionados com as variáveis de consumo e pode, por conseguinte, compor equações para predizer o consumo a partir da avaliação do comportamento ingestivo. O número de bocados realizados por dia contribui para a ingestão de novilhas em pastagem.

Palavras-chave: Bovino, alimentação, ingestão, ruminação

\section{Introduction}

The ingestive behavior of grazing ruminants has been used to guide and underpin several discussions associated with intake. Thus, measurements of these correlations may break some paradigms because, probably, not all behavior variables correlate with nutritional parameters.

There are variables associated with eating behavior and some nutrients that tend to correlate with the total intake by pasture-grazed bovine animals. Grazing time, rate and mass of mouthful are limiting factors that may render the animal unable to swallow dry matter (DM). Another mechanism that also limits intake is the time required to fragment the particles of food, which is measured through rumination, since it determines the time food remains in the gastrointestinal tract. In this case, the digestive process turn out to be more narrowly focused, where the passing and capacity of the gastrointestinal tract play an important role (LACA; DEMMENT, 1992).

In order to better understand the basic factors that affect intake, it is necessary that the ability to measure it is improved so that the influences of both variables (animal and diet) can be better defined and strategies aimed at the optimization of the production process are developed (DETMANN et al., 2001). 
Carvalho et al. (2007) have reported that intake by pasture-grazed animals cannot be directly determined; then, multiple methodologies have been developed to estimate it. Accordingly, further knowledge of the ingestive behavior variables that inter-correlate with intake is needed to make clear which variables should form a mathematical model that determines intake through eating behavior.

The origin of such proposition is based on the study of Allden and Whittaker (1970), who proposed that the daily intake of a grazing animal should be the result of grazing time multiplied by the mouthful rate. This concept was improved by Rook (2000), who proposed that intake was the total mouthful mass (MaM), mouthful rate (MR), duration of meals (DM) and the number of meals (NM) during the day, where:

$$
\text { Intake }=(\text { MaM } \times \text { MR }) \times(D M \times N M)
$$

Despite the use of behavioral variables have great potential to estimate intake, unfortunately there has been a banalization of their use by many researchers who apply them so detached from any predictive model and without accurate investigation of the cause and effect relationships regarding the grazing process. They have only been used as "emerging variables" and treated as mere additional information in scientific publications, especially the national editions (CARVALHO et al., 2007).

The objective of this study was to evaluate the correlation between intake and ingestive behavior of crossbred heifers in grazing tropical.

\section{Material and Methods}

The experiment was conducted on the Princesa do Mateiro Farm, in the city of Ribeirão do Largo, Bahia. A total of 20 heifers with genetic makeup 5/8 dairy Guzerá and 3/8 Holstein, average age of 18 months and average initial body weight of 187 $\pm 13.1 \mathrm{~kg}$ have been used. The experiment lasted 224 days, from May 25, 2008 to January 4, 2009, comprising four periods of 56 days.

The animals were raised in a rotational grazing system with Brachiaria brizantha cv. Marandú, in an area of 10 ha divided into four paddocks of equivalent areas sealed 30 days before the start of the experiment.

Concentrate supplementation was daily provided to animals (Table 1) always at 10:00 a.m., in aggregating plastic troughs, with double access, a linear dimension of $80 \mathrm{~cm} /$ animal and no cover.

Table 1. Proportion of concentrate ingredients per period in the base of the natural matter.

\begin{tabular}{lcccc}
\hline \multirow{2}{*}{ INGREDIENT } & \multicolumn{4}{c}{ PERIOD } \\
\cline { 2 - 5 } & 1 & 2 & 3 & 4 \\
\hline Milled grains of maize & 28.20 & 66.47 & 70.52 & 72.05 \\
Soybean meal & 34.08 & 26.75 & 25.92 & 25.21 \\
Wheat meal & 35.20 & 5.28 & 0.08 & --- \\
Calcitic limestone & 1.32 & --- & 0.67 & 0.84 \\
Dicalcium phosphate & --- & --- & 0.51 & --- \\
Urea & --- & --- & --- & 0.36 \\
Mineral salt ${ }^{1}$ & 1.20 & 1.50 & 2.30 & 1.54 \\
\hline
\end{tabular}

${ }^{1}$ Composition: Calcium 140 g; phosphorus 65 g; 148 g sodium; magnesium $5 \mathrm{~g}$; sulfur $12 \mathrm{~g}$; $107 \mathrm{mg}$ cobalt; $1550 \mathrm{mg}$ copper; iodine $150 \mathrm{mg}$; manganese $1400 \mathrm{mg}$; nickel 30mg; selenium $18 \mathrm{mg}$; zinc $4500 \mathrm{mg}$; $1120 \mathrm{mg}$; fluoride (maximum) $650 \mathrm{mg}$. Source: Elaboration of the authors.

The animals were identified in the experimental units by their morphological characteristics and through plastic earrings.

Simulated grazing samples were obtained through the use of experimental animals, according to Johnson (1978), also, the type of material consumed was identified and a similar sample of the food ingested was collected (Table 2).

In order to estimate fecal output, chromium oxide has been used as an external indicator daily provided at 09:00 a.m. in a single dose of $10 \mathrm{~g}$ wrapped for 12 days, whereof 7 were assigned for adaptation and regulation of marker excretion flow and 5 were assigned for fecal collection. 
Table 2. Composition of supplements (SU) and simulated grazing (SG) in the respective experimental periods.

\begin{tabular}{lrrrrrrrr}
\hline \multirow{2}{*}{ Variable } & \multicolumn{9}{c}{ PERIOD } \\
\cline { 2 - 9 } & \multicolumn{1}{c}{ SG } & \multicolumn{1}{c}{ SU } & \multicolumn{1}{c}{ SG } & \multicolumn{1}{c}{ SU } & \multicolumn{1}{c}{ SG } & \multicolumn{1}{c}{ SU } & \multicolumn{1}{c}{ SG } & \multicolumn{1}{c}{ SU } \\
\cline { 2 - 8 } & 27.45 & 91.23 & 25.34 & 90.56 & 40.05 & 90.45 & 24.87 & 90.76 \\
DM & 12.23 & 22.56 & 11.09 & 20.26 & 8.78 & 19.49 & 15.13 & 20.20 \\
CP (\% DM) & 2.65 & 2.89 & 2.76 & 2.67 & 2.35 & 3.45 & 2.69 & 3.65 \\
EE (\% DM) & 20.78 & 58.71 & 18.56 & 57.42 & 14.78 & 55.65 & 17.34 & 54.83 \\
NFC (\% DM) & 72.08 & 15.31 & 75.73 & 17.48 & 78.39 & 16.08 & 67.75 & 16.88 \\
NDFap (\% DM) & 32.05 & 4.89 & 34.98 & 5.11 & 37.62 & 5.17 & 30.97 & 5.52 \\
ADF (\% DM) & 5.78 & 4.95 & 6.09 & 5.05 & 6.20 & 5.03 & 5.89 & 55.15 \\
Ash (\% DM) & 69.07 & 77.19 & 68.35 & 81.63 & 58.79 & 80.5 & 67.89 & 81.2 \\
TDN (\% DM) & & & & & & & &
\end{tabular}

DM - dry matter, CP - crude protein, EE - extract ether; CNF - non-fibrous carbohydrates, NDFap - neutral detergent fiber corrected for ash and protein, ADF - acid detergent fiber, TDN - total digestible nutrients.

Source: Elaboration of the authors.

Feces were collected once a day in the same paddock, for five days, always after the intake of concentrate. The collection of feces was accurately conducted so as to avoid foreign body contamination. Fecal samples were afterwards stored in cold storage, at $-10^{\circ} \mathrm{C}$. Fecal samples were analyzed by atomic absorption spectrophotometry (AAS) for determination of chromium, according to Willians, David e Lilma (1962). The determination of fecal production was performed according to the equation proposed by Smith e Reid (1955): FO = $\mathrm{PO} / \mathrm{COF}$, where FO is the daily fecal output (g/day); PO stand for chromium oxide provided (g/day) and COF refers to the concentration of chromium oxide in feces $(\mathrm{g} / \mathrm{g} \mathrm{DM})$.

For the purpose of determining the internal indicator, indigestible acid detergent fiber (iADF) (CASALI et al., 2008), samples of forage, feces and concentrates were incubated in the rumen of four fistulated animals, for $264 \mathrm{~h}$ (CASALI et al., 2008), which residue was assumed to be indigestible.

Dry matter intake was calculated through the following equation (Table 3$): \mathrm{DMI}=\{[(\mathrm{FO} * \mathrm{CIFC})$ - IS]/CIFR $\}$ + DMIS; that DMI stands for dry matter intake ( $\mathrm{kg} /$ day), FO refers to fecal output ( $\mathrm{kg} /$ day); CIFC concentration of the indicator present in feces $(\mathrm{kg} / \mathrm{kg})$; IS refers to the indicator present in the supplement ( $\mathrm{kg} /$ day); CIFR refers to the concentration of the indicator present in forage $(\mathrm{kg} / \mathrm{kg})$ and DMIS stands for the dry matter intake of supplement ( $\mathrm{kg} /$ day).

Table 3. Crossbred heifers of intake in grazing tropical.

\begin{tabular}{lc}
\hline \multicolumn{1}{c}{ Variable } & $\mathrm{Kg}$ /day \\
\hline Dry matter intake of the supplement & 2.74 \\
Dry matter intake of forage & 2.93 \\
Total dry matter intake & 5.51 \\
Neutral detergente fiber intake & 2.69 \\
Non fiber carbohydrates intake & 1.75 \\
Crude protein intake & 0.86 \\
Total digestible nutrientes intake & 3.54 \\
\hline
\end{tabular}

Source: Elaboration of the authors.

The analysis of DM, organic matter $(\mathrm{OM})$, crude protein $(\mathrm{CP})$, ether extract (EE), neutral detergent fiber (NDF) and acid detergent fiber (ADF) were obtained as described by Silva and Queiroz (2002). The NDF content corrected for ash and protein was performed following the recommendations of Mertens (2002). The total carbohydrates (TCH) were obtained through the following equation: 100 (\%CP + \% EE + \% Ash) (Sniffen et al., 1992), while the non-fibrous carbohydrates (NFC) were calculated based on the difference between TCH and NDFpa. 
The levels of total digestible nutrients (TDN) were calculated according to the recommendations of Weiss (1999), but using the NFC and NDF corrected for ash and protein, through the following equation: $\mathrm{TDN}(\%)=\mathrm{DCP}+\mathrm{DNDFpa}+\mathrm{DNFC}+2.25 \mathrm{DEE}$; where: $\mathrm{DCP}=$ digestible crude protein; $\mathrm{DNDF} p=$ digestible NDFpa; DNFC = digestable NFC; and $\mathrm{DEE}=$ digestable EE.

The evaluation of behavior was held on the $28^{\text {th }}$ day of each period, totaling four assessments with observations made every 10 minutes, for 24 hours, as proposed by Silva et al. (2008), to identify the time allocated to grazing, rumination, feeding at the trough and other activities. The animals were visually evaluated by two observers especially trained for each treatment, strategically positioned so as not to disturb the animals. In order to find out how much time was spent on each activity, digital watches have been used. There was no need for artificial lighting during night time, since the collection period has coincided with the full moon phase in all evaluations (every 56 days, which equals to 2 moon cycles).

The behavioral variables studied were: grazing time (GRA), rumination time (RUM), feeding time at the trough (FTT) and time spent on other activities (OTH). The behavioral activities were considered mutually exclusive, as defined by Pardo et al. (2003).

The time spent by animals in the selection of forage and seizure, including the short period of time used to move to the selection of forage grazing time was considered (HANCOCK, 1953). The time spent on rumination corresponded to the processes of regurgitation, rechewing, reinsalivation and redeglutition. The time spent on feeding at the trough was that spent by the animal in consuming the supplement. The time in other activities (resting, water intake, interactions etc.), in turn, was that allotted to all activities but those above mentioned.

The variables referring to total feeding time (TFT) and total chewing time (TCT) were determined by the equations below: TFT $=$ PAS + FIT, where: GRA (minutes) = grazing time; FTT (minutes) = time spent on feeding at the trough; TCT = PAS + RUM + FTT, where: GRA (minutes) = grazing time; RUM (minutes) = ruminating time; FTT (minutes) $=$ time spent on feeding at the trough.

Discretization of the time series was directly made in data collection spreadsheets, including the count of periods of discrete feeding, rumination and resting, as described by Santana Júnior et al. (2013). The average duration of each discrete period was obtained by dividing the day-time of every activity by the number of discrete periods of the respective activity.

Observations were made in two periods of the day (morning and afternoon) and three replicates per period, so that the number of chews per ruminated bolus (NCB) and the time spent on ruminating each bolus (TBo) were determined.

The variables of rumination aspects, number of boli ruminated per day (BOL), chewing speed (ChS), time spent chewing ( TcW) and daily number of chews per bolus (DNC), were calculated through the following equations of Santana Júnior et al. (2012).

During the same periods of evaluation of animal behavior - when the animals were grazing for more than 30 minutes - the mouthful rate (MR) was recorded for animals of each treatment and estimated by the time spent by the animal to take 20 mouthfuls (HODGSON, 1982). In order to calculate the mass of mouthfuls (MaM), the total daily intake was divided by the total number of mouthfuls taken each day (JAMIESON; HODGSON, 1979).

The number of mouthfuls and the time spent on swallowing were also recorded. Results of observations of mouthfuls and swallowing were recorded on six different times in the day, as recommended by Baggio et al. (2009); three evaluations in the morning and three in the afternoon, also used to determine the number of mouthfuls per day (NMD), indicating the result of mouthful rate 
multiplied by grazing time.

Correlations were made by analysis of Pearson's linear correlation coefficient and " $t$ " test, processed using the SAGE software - Statistical Analysis for Genetic Epidemiology - and considered significant when $\mathrm{P}<0.05$. The following parameters have been used:

- Intake: Total dry matter intake (TDMI), organic matter intake (OMI), dry matter intake of forage (DMIF), dry matter intake of the supplement (DMIS), neutral detergent fiber intake (NDFI), total digestible nutrient intake (TDNI), non-fibrous carbohydrate intake (NFCI), total carbohydrate intake (TCHI), crude protein intake (CPI), ether extract intake (EEI);

- Ingestive behavior: grazing time (GRA), rumination time (RUM), feeding time at the trough (FTT), time spent in other activities (OTH), total feeding time (TFT), total chewing time (TCT), number of grazing periods (NGP), number of rumination periods (NRP), number of periods feeding at the trough (NPT) and number of periods spent on other activities (NPO), time per grazing period (TGP), time per rumination period (TRP), time per feeding period at the trough (TPT), time per period spent on other activities (TPO), mouthful rate (MR), mouthful mass (MaM), number of mouthfuls per deglutition (NMD), time per deglutition (TDe), number of mouthfuls per day (NMD), number of chews per bolus (NCB), time per ruminated bolus (TRB), chewing speed (ChS), time per chewing (TcW), daily number of chews (DNC), daily number of ruminated bolus (BOL).

\section{Results and Discussion}

The variables with $\mathrm{P}$-values significance above that established $(\mathrm{P}<0.05)$ are not described in the table. The grazing time was not correlated with any of the variables of intake (Table 4). This study is not in consonance with Gontijo Neto, Euclides and Nascimento Júnior (2006), who reported that grazing time was highly correlated with forage intake and can be used to develop models to predict forage intake and animal performance on pasture. It is believed that this lack of correlation in grazing time is due to factors that lead to changes on it and that are not directly associated with intake, but with the conditions of the forage canopy, as an increase in grazing time could be explained by the low height of pasture, which does not provoke an increase in intake.

Rumination time showed positive correlations with dry matter intake of forage, neutral detergent fiber intake, dry matter intake of forage in body weight percentage, neutral detergent fiber intake in body weight percentage. In this study, the basal diet consisted of grass; then, the main source of neutral detergent fiber in the diet was forage and a similar effect involving dry matter intake of forage and neutral detergent fiber intake was expected. Rumination is a process whose main objective is to reduce the size of particles; the increase in dry matter intake of forage will raise the neutral detergent fiber intake and that will result in more time spent on rumination. A previous study has verified the correlation observed in rumination time, as Mertens (1997) has investigated the relationship between rumination and neutral detergent fiber intake. 
Table 4. Linear correlations between ingestive behavior and intake by pasture-grazed crossbred heifers.

\begin{tabular}{lcccccccccccc}
\hline \multirow{2}{*}{ Variable } & \multicolumn{3}{c}{ GRA } & \multicolumn{2}{c}{ RUM } & \multicolumn{3}{c}{ OTH } & \multicolumn{3}{c}{ FTT } & \multicolumn{2}{c}{ TFT } & \multicolumn{2}{c}{ TCT } \\
\cline { 2 - 12 } & r & P & r & P & R & P & r & P & r & P & r & P \\
\hline TDMI & --- & --- & --- & --- & --- & --- & --- & --- & --- & --- & --- & --- \\
OMI & --- & --- & --- & --- & --- & --- & --- & -- & --- & --- & --- & --- \\
DMIF & --- & --- & 0,63 & 0,0454 & --- & --- & --- & --- & --- & --- & --- & --- \\
DMIS & --- & --- & --- & --- & --- & --- & --- & --- & --- & --- & --- & --- \\
NDFI & --- & --- & 0,65 & 0,0416 & --- & --- & --- & --- & --- & --- & --- & --- \\
TDNI & --- & --- & --- & --- & --- & --- & --- & --- & --- & --- & --- & --- \\
NFCI & --- & --- & --- & --- & --- & --- & --- & --- & --- & --- & --- & --- \\
TCHI & --- & --- & --- & --- & --- & --- & --- & --- & --- & --- & --- & --- \\
CPI & --- & --- & --- & --- & --- & --- & --- & --- & --- & --- & --- & --- \\
EEI & --- & --- & --- & --- & --- & --- & --- & --- & --- & --- & --- & --- \\
TDMI & --- & --- & --- & --- & --- & --- & --- & --- & --- & --- & --- & --- \\
DMIF $_{\%}$ & --- & --- & 0,64 & 0,0445 & $-0,62$ & 0,0487 & --- & --- & --- & --- & --- & --- \\
DMIS $_{\%}$ & --- & --- & --- & --- & $-0,63$ & 0,0453 & --- & --- & --- & --- & --- & --- \\
NDFI $_{\%}$ & $-0,63$ & 0,0480 & $-0,63$ & 0,0480 & $-0,63$ & 0,0480 & $-0,63$ & 0,0480 & $-0,63$ & 0,0480 & $-0,63$ & 0,0480 \\
\hline
\end{tabular}

GRA - grazing time; RUM - rumination time; OTH - time spent in other activities; FTT - feeding time at the trough; TFT - total feeding time; TCT - total chewing time; TDMI - total dry matter intake; OMI - organic matter intake; DMIF - dry matter intake of forage; DMIS - dry matter intake of the supplement; NDFI - neutral detergent fiber intake; TDNI - total digestible nutrient intake; NFCI - non-fibrous carbohydrate intake; TCI - total carbohydrate intake; CPI - crude protein intake; EEI - ether extract intake; $\mathrm{TDMI}_{\%}$ - total dry matter intake in body weight percentage; $\mathrm{DMIF}_{\%}$ - dry matter intake of forage in body weight percentage; DMIS - dry matter intake of the supplement in body weight percentage; $\mathrm{NDFI}_{\%}$ - neutral detergent fiber intake in body weight percentage. Significance values $(\mathrm{P}<0.05)$ are shown between parentheses.

Source: Elaboration of the authors.

Negative correlations were found between the time spent on time spent in other activities (OTH), dry matter intake of forage in body weight percentage and dry matter intake of the supplement in body weight percentage. Despite OTH consists of activities without nutritional significance (rest, interactions etc.), the behavioral activities are mutually exclusive; hence, the animal could not be grazing at the same time, and, the greater the intake of forage and supplement, the higher the demand for grazing time and feeding at the trough. The variables feeding time at the trough, total feeding time and total chewing time were not observed to correlate with intake.
Positive correlations were found between number of grazing periods and number of rumination periods with total dry matter intake $(r=0.91 ; r=$ $0.92)$, organic matter intake $(r=0.92 ; r=0.93)$, dry matter intake of forage $(r=0.95 ; r=0.94)$, neutral detergent fiber intake $(r=0.94 ; r 0.94)$, total carbohydrate intake $(r=0.92 ; r=0.94)$, ether extract intake $(r=0.93 ; r=0.91)$, total dry matter intake in body weight percentage $(r=0.94 ; r=0.93)$, dry matter intake of forage in body weight percentage $(\mathrm{r}$ $=0.93 ; \mathrm{r}=0.90)$, respectively (Table 5 ). Some very high correlations $(r>0.90)$ were observed above and can be used in the design of intake prediction equations based on ingestive behavior. 


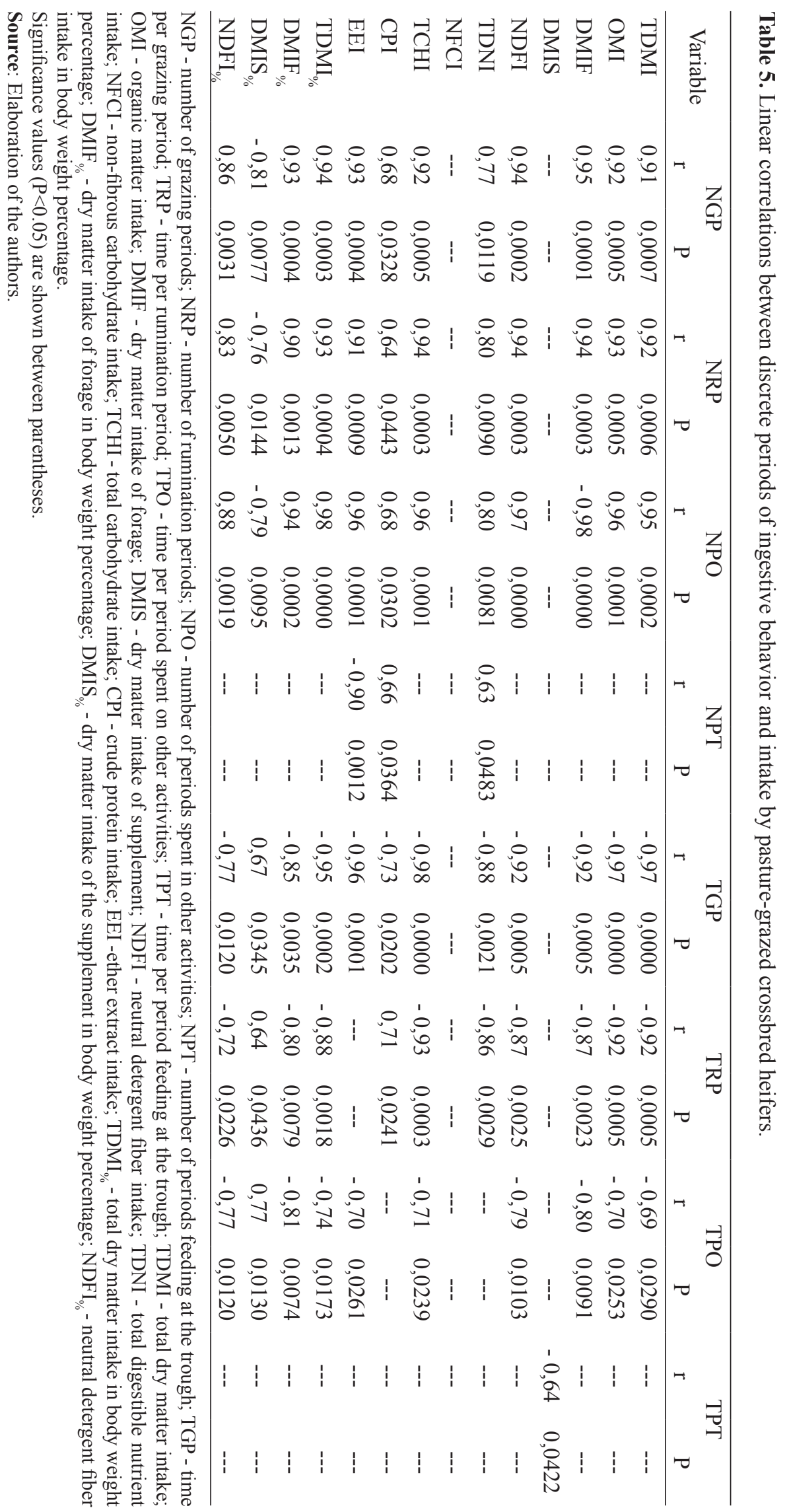


Total digestible nutrient intake, total dry matter intake, neutral detergent fiber intake in body weight percentage showed positive correlations with number of grazing periods and number of rumination periods, since the increase in the number of grazing periods leads to higher intake of nutrients. On the other hand, number of rumination periods results from total dry matter intake in body weight percentage. Number of grazing periods and number of rumination periods showed negative correlations with total dry matter intake in body weight percentage.

Number of other activities periods showed positive and significant correlations with total dry matter, organic matter, dry matter of forage in percentage of weight body, neutral detergent fiber in $\mathrm{kg}$ and body weight percentage, total digestible nutrient, total carbohydrate, crude protein, ether extract and dry matter of forage intakes, whereas the correlations between number of periods spent in other activities and the intake variables follow the same discussion addressing other activities. Negative correlations were found for number of periods spent in other activities, involving dry matter intake of forage and dry matter intake of the supplement in body weight percentage. The lower the number of periods spent on other activities, the higher is the tendency to intake.

The number of periods feeding at the trough (NPT) showed positive correlations with total digestible nutrient intake, total dry matter intake, and negative correlations with ether extract intake. There have been positive correlations due to the fact that the highest NPT was associated with a higher supply of supplement, which had a higher content of total digestible nutrient and crude protein.

Time per grazing period showed correlations inversely proportional to number of grazing periods, since the elevation of one variable causes a decrease in another variable. Time per rumination period was positively correlated with DMI, dry matter intake of the supplement in body weight percentage, and negatively correlated with total and the supplement dry matter in $\mathrm{kg}$ and body weight percentage, organic matter, dry matter of forage in percentage, neutral detergent fiber in $\mathrm{kg}$ and body weight percentage, total digestible nutrient, total carbohydrate intakes. The higher intake of dry matter observed in this study was due to the increased intake of forage, promoting increased rumination activity, for the animals were observed to perform these activities, the increase in rumination leads to a higher frequency of periods spent on these activities; hence, there is a decrease in period of time spent on rumination.

The number of periods spent in other activities was negatively correlated with total dry matter, organic matter, dry matter of forage in percentage, neutral detergent fiber, non-fibrous carbohydrate, total carbohydrate, ether extract and total and supplement, neutral detergent fiber, dry matter in body weight percentage intakes. According to the concept that behavioral activities that are mutually exclusive, number of periods spent in other activities is associated with other activities, when the animal is not eating. Negative correlations were observed between number of periods feeding at the trough and dry matter intake of supplement, and when the provision of supplements was elevated, a higher number of periods occur, resulting in less time per period, considering that the time spent on each period is obtained by the division of the total time spent on the activity by the number of periods in the same activity.

The mouthful rate was positively correlated with total dry matter, organic matter, dry matter of forage in percentage, neutral detergent fiber, total carbohydrate, total digestible nutrient, ether extract, dry matter and total dry matter in body weight percentage intakes and DMIS $\%$ (Table 4). When the mouthful rate is elevated, it provokes higher intake. Because of the correlation with almost all variables of intake in the study, mouthful rate may be of importance in defining equations for predicting intake by grazing animals. According to Galli, Cangiano and Fernández (1996) and Berchielli, 
Pires and Oliveira (2011), variations in the mass per mouthful do not lead to differences in intake, by reason of the compensation rates of mouthfuls.

Regarding number of mouthfuls per day, the lack of correlation with intake leads to the assumption that there has been compensation in time per deglutition, for it correlated with the intake variables.

The time per deglutition has correlated negatively with total dry matter, organic matter, neutral detergent fiber, total carbohydrate, ether extract, total dry matter in body weight percentage intakes, $\mathrm{DMIS}_{\%}$ and $\mathrm{NDFI}_{\%}$ (Table 6). The time per deglutition is that spent by the animal until it reaches the volume desired to swallowing; then, the higher the time spent on deglutition, the greater the digestibility, as a result of the longer permanence of food in the gastrointestinal tract. In inverse proportion, high intake can be only achieved with reduced time per deglutition, what should result in greater speed of ingestion.

Table 6. Linear correlations between mouthfuls and deglutitions, and intake by pasture-grazed crossbred heifers.

\begin{tabular}{|c|c|c|c|c|c|c|c|c|c|c|}
\hline \multirow{2}{*}{ Variável } & \multicolumn{2}{|c|}{ MR } & \multicolumn{2}{|c|}{$\mathrm{MaM}$} & \multicolumn{2}{|c|}{ MDe } & \multicolumn{2}{|c|}{ TDe } & \multicolumn{2}{|c|}{ NMD } \\
\hline & $\mathrm{R}$ & $\mathrm{P}$ & $\mathrm{R}$ & $\mathrm{P}$ & $\mathrm{r}$ & $\mathrm{P}$ & $\mathrm{r}$ & $\mathrm{P}$ & $r$ & $\mathrm{P}$ \\
\hline TDMI & 0,83 & 0,0054 & --- & --- & --- & --- & $-0,73$ & 0,0199 & 0,75 & 0,0155 \\
\hline OMI & 0,83 & 0,0057 & --- & --- & --- & --- & $-0,73$ & 0,0191 & 0,76 & 0,0141 \\
\hline DMIF & 0,75 & 0,0155 & --- & --- & --- & --- & -- & -- & 0,79 & 0,0100 \\
\hline DMIS & --- & --- & --- & --- & --- & --- & --- & --- & --- & --- \\
\hline NDFI & 0,74 & 0,0170 & --- & --- & --- & --- & $-0,73$ & 0,0198 & 0,76 & 0,0137 \\
\hline TDNI & 0,76 & 0,0136 & --- & --- & -- & --- & -- & -- & 0,64 & 0,0425 \\
\hline NFCI & --- & --- & --- & --- & --- & --- & --- & --- & --- & --- \\
\hline TCHI & 0,83 & 0,0053 & --- & --- & -- & --- & $-0,73$ & 0,0201 & 0,76 & 0,0134 \\
\hline CPI & 0,67 & 0,0345 & --- & --- & -- & --- & -- & -- & --- & -- \\
\hline EEI & 0,80 & 0,0089 & --- & --- & -- & --- & $-0,79$ & 0,0096 & 0,72 & 0,0223 \\
\hline TDMI $_{\%}$ & 0,78 & 0,0115 & --- & --- & --- & --- & $-0,76$ & 0,0136 & 0,72 & 0,0224 \\
\hline DMIF $_{\%}{ }^{\circ}$ & 0,66 & 0,0373 & --- & --- & --- & --- & $-0,70$ & 0,0268 & 0,75 & 0,0158 \\
\hline DMIS $_{\%}{ }^{{ }_{0}}$ & --- & -- & --- & --- & --- & --- & --- & -- & $-0,69$ & 0,0294 \\
\hline $\mathrm{NDFI}_{0 \%}{ }^{\circ}$ & --- & --- & --- & --- & --- & --- & $-0,66$ & 0,0368 & 0,66 & 0,0366 \\
\hline
\end{tabular}

MR - mouthful rate; MaM - mouthful mass; MDe - number of mouthfuls per deglutition; TDe - time per deglutition; NMD number of mouthfuls per day; TDMI - total dry matter intake; OMI - organic matter intake; DMIF - dry matter intake of forage; DMIS - dry matter intake of supplement; NDFI - neutral detergent fiber intake; TDNI - total digestible nutrient intake; NFCI - nonfibrous carbohydrate intake; TCI - total carbohydrate intake; CPI - crude protein intake; EEI - ether extract intake; TDMI $_{\%}$ - total dry matter intake in body weight percentage; $\mathrm{DMIF}_{\%}$ - dry matter intake of forage in body weight percentage; DMIS ${ }_{\%}$ - dry matter intake of the supplement in body weight percentage; $\mathrm{NDFI}_{\%}$ - neutral detergent fiber intake in body weight percentage.

Significance values $(\mathrm{p}<0.05)$ are shown between parentheses.

Source: Elaboration of the authors.

There were positive correlations between number of mouthfuls per day and total dry matter, organic matter, dry matter of forage, neutral detergent fiber, total carbohydrate, total digestible nutrient, ether extract, total dry matter in body weight percentage, dry matter of forage in body weight percentage intakes, $\mathrm{NDFI}_{\%}$, and negative correlation with
DMIS $_{\%}$. One can note that, the greater the number of mouthfuls per day, the higher the intake; that can be explained by the higher catch and ingestion of food by the ruminant. Yet, it should be noted that the greater the intake of supplement as a function of body weight, the lower the number of mouthfuls per day. This correlation between mouthfuls performed 
in 24 hours and intake variables reinforces that it may vary depending on the intake of some nutrients; still, this assertion comes at odds with Berchielli, Pires and Oliveira (2011), as these authors defend that only minor variations occur in number of mouthfuls per day and that the variation in intake results from change in the mouthful mass.

The number of chews per bolus showed negative correlations with dry matter of the supplement, non-fibrous carbohydrate and crude protein intakes (Table 7), and that was explained by the fact that the higher the DM intake from the supplement, the greater the intake of non-fibrous carbohydrates and protein, once the supplement is a source of NFC and $\mathrm{CP}$; these nutrients do not therefore stimulate chewing, keeping in mind that they are poor in effective fiber.

Table 7. Linear correlations between aspects regarding rumination, ingestive behavior and intake by pasture-grazed crossbred heifers.

\begin{tabular}{|c|c|c|c|c|c|c|c|c|c|c|c|c|}
\hline \multirow{2}{*}{ Variável } & \multicolumn{2}{|c|}{ NCB } & \multicolumn{2}{|c|}{ TBo } & \multicolumn{2}{|c|}{$\mathrm{ChS}$} & \multicolumn{2}{|c|}{$\mathrm{TcW}$} & \multicolumn{2}{|c|}{$\mathrm{DNC}$} & \multicolumn{2}{|c|}{$\mathrm{BOL}$} \\
\hline & $\mathrm{r}$ & $\mathrm{P}$ & $\mathrm{r}$ & $\mathrm{P}$ & $\mathrm{r}$ & $\mathrm{P}$ & $\mathrm{r}$ & $\mathrm{P}$ & $\mathrm{r}$ & $\mathrm{P}$ & $\mathrm{r}$ & $\mathrm{P}$ \\
\hline TDMI & --- & --- & --- & --- & --- & --- & --- & --- & --- & --- & --- & --- \\
\hline OMI & --- & --- & --- & --- & --- & --- & --- & --- & --- & --- & --- & --- \\
\hline DMIF & --- & --- & --- & --- & --- & --- & --- & --- & 0,65 & 0,0401 & 0,62 & 0,494 \\
\hline DMIS & $-0,73$ & 0,0199 & --- & --- & --- & --- & --- & --- & --- & --- & --- & --- \\
\hline NDFI & --- & --- & --- & --- & --- & --- & --- & --- & --- & 0,0355 & --- & --- \\
\hline TDNI & --- & --- & $-0,69$ & 0,0289 & --- & --- & --- & --- & --- & --- & --- & --- \\
\hline NFCI & $-0,74$ & 0,0172 & $-0,77$ & 0,0124 & --- & --- & --- & --- & --- & --- & --- & --- \\
\hline TCHI & --- & --- & --- & --- & --- & --- & --- & --- & --- & --- & 0,62 & 0,0476 \\
\hline CPI & $-0,66$ & 0,0376 & $-0,69$ & 0,0279 & --- & --- & --- & --- & --- & --- & --- & --- \\
\hline EEI & --- & --- & --- & --- & --- & --- & --- & --- & --- & --- & --- & --- \\
\hline TDMI $_{\%}$ & --- & --- & --- & --- & --- & --- & --- & --- & --- & --- & --- & --- \\
\hline $\mathrm{DMIF}_{\%}$ & --- & --- & --- & --- & --- & --- & --- & --- & 0,66 & 0,0371 & --- & --- \\
\hline DMIS $_{\%}{ }^{\%}$ & --- & --- & --- & --- & $-0,62$ & 0,0491 & --- & --- & $-0,64$ & 0,0433 & --- & --- \\
\hline $\mathrm{NDFI}_{0}$ & --- & --- & --- & --- & --- & --- & --- & --- & 0,66 & 0,0384 & --- & --- \\
\hline
\end{tabular}

NCB - number of chews per bolus; TBo - time per ruminated bolus; ChS - chewing speed; TcW - time per chewing; DNC - daily number of chews; BOL - number bolus per day; TDMI - total dry matter intake; OMI - organic matter intake; DMIF - dry matter intake of forage; DMIS - dry matter intake of supplement; NDFI - neutral detergent fiber intake; TDNI - total digestible nutrient intake; NFCI - non-fibrous carbohydrate intake; THCI - total carbohydrate intake; CPI - crude protein intake; EEI - ether extract intake; $\mathrm{TDMI}_{\%}$ - total dry matter intake in body weight percentage; DMIF ${ }_{\%}$ - dry matter intake of forage in body weight percentage; DMIS $_{\%}$ - dry matter intake of the supplement in body weight percentage; $\mathrm{NDFI}_{\%}$ - neutral detergent fiber intake in body weight percentage.

Significance values $(\mathrm{P}<0.05)$ are shown between parentheses.

Source: Elaboration of the authors.

One of the pioneering studies conducted by Stobbs (1973) and Chacon and Stobbs (1976) on tropical forage plants revealed the importance of the mouthful mass as compared to the other components of ingestive behavior. Hodgson (1985) and Bremm et al. (2008) have likewise confirmed that, saying that the mass contained in the mouthful is the most important variable in determining intake by grazing animals; yet, the same was not observed in this study, since the mouthful mass was not correlated with any of the intake variables.

Time per ruminated bolus was negatively correlated with non-fibrous carbohydrate, total digestible nutrient and crude protein intakes. There has been a negative correlation between chewing 
speed and dry matter intake of supplement. Both time per ruminated bolus and chewing speed are in consonance with the rationale of number of chews per bolus.

The daily number of chews showed positive correlations with dry matter of forage, neutral detergent fiber intakes, $\mathrm{DMIF}_{\%}$ and $\mathrm{NDFI}_{\%}$ and negative correlation with DMIS $_{\%}$. It should be noted that, for a higher intake of NDF - which is only achieved with increased forage intake - there is a higher more chewing activity during the day. It should be pointed out that there is a negative association between the supplement and the activities regarding rumination (MISSIO et al., 2010).

The number bolus per day showed positive correlations with dry matter of the supplement and total carbohydrate intakes. Number bolus per day varies according to dry matter intake of forage, as forage is a source of NDF and the elevation of NDF content in the diet promotes more ruminated boli per day. The increased NDF content results in higher total carbohydrate content, since the NDF is considered as a source of carbohydrates, hence, the increase in total carbohydrate intake indirectly promotes greater number bolus per day.

The time per chewing has not had a significant correlation with intake, probably due to the compensation in chewing speed, as the chewing of certain amount of bolus requires a certain amount of time per chewing; yet, if an increase in the mass of bolus does not coincide with a change in time per chewing, changes in chewing speed should be expected.

At odds with the national and international literature, grazing time was not correlated with intake by pasture-grazed crossbred heifers.

The number of activities, the time spent on them and the mouthful rate where shown to be highly associated with the intake variables and can therefore arrange equations to predict intake through the analysis of feeding behavior. The number of mouthfuls performed each day contributes to the intake by pasture-grazed heifers.

The article was approved by the bioethics committee and was conducted according to the standards of biosafety and ethics.

\section{Acknowledgement}

When Banco do Nordeste do Brasil by funding research.

\section{References}

ALLDEN, W. G.; WHITTAKER, A. M. The determinants of herbage intake by grazing sheep: the interrelationship of factors influencing herbage intake and availability. Australian Journal Agricultural Research, Canberra, v. 21, n. 5, p. 755, 1970.

BAGgio, C.; CARVAlHO, P. C. F.; SILVA, J. L. S.; ANGHINONI, I.; LOPES, M. L. T.; THUROW, J. M. Padrões de deslocamento e captura de forragem por novilhos em pastagem de azevém-anual e aveia-preta manejada sob diferentes alturas em sistema de integração lavoura-pecuária. Revista Brasileira de Zootecnia, Viçosa, MG, v. 38, n. 2, p. 215-222, 2009.

BERCHIELLI, T. T.; PIRES, A. V.; OLIVEIRA, S. G. (Ed.). Nutrição de ruminantes. 2. ed. Jaboticabal: FUNEP, 2011. $616 \mathrm{p}$.

BREMM, C., ROCHA, M. G.; FREITAS, F. K.; MACARI, S.; ELEJALDE, D. A. J.; ROSO, D. Comportamento ingestivo de novilhas de corte submetidas a estratégias de suplementação em pastagens de aveia e azevém. Revista Brasileira de Zootecnia, Viçosa, MG, v. 37, n. 7, p. 11611167, 2008.

CARVALHO, P. C. F.; KOZLOSKI, G. V.; RIBEIRO FILHO, H. M. N.; REFFATTI, M. V.; GENRO, T. C. M.; EUCLIDES, V. P. B. Avanços metodológicos na determinação do consumo de ruminantes em pastejo. Revista Brasileira de Zootecnia, Viçosa, MG, v. 36, p. 151-170, 2007. Suplemento.

CASALI, A. O.; DETMANN, E.; VALADARES FILHO, S. C.; PEREIRA, J. C.; HENRIQUES, L. T.; FREITAS, S. G.; PAULINO, M. F. Influência do tempo de incubação e do tamanho de partículas sobre os teores de compostos indigestíveis em alimentos e fezes bovinas obtidas por procedimentos in situ. Revista Brasileira de Zootecnia, Viçosa, MG, v. 37, n. 2, p. 335-342, 2008.

CHACON, E.A.; STOBBS, T. H. Influence of progressive 
defoliation of a grass sward on the eating behaviour of cattle. Australian Journal of Agricultural Research, v. 27, n. 5, p. 709-727, 1976.

DETMANN, E.; PAULINO, M. F.; ZERVOUDAKIS, J. T.; VALADARES FILHO, S. C.; EUCLIDES, R. F.; LANA, R. P.; QUEIROZ, D. S. Cromo e indicadores internos na determinação do consumo de novilhos mestiços, suplementados, a pasto. Revista Brasileira de Zootecnia, Viçosa, MG, v. 30, n. 5, p. 1600-1609, 2001.

GALLI, J. R.; CANGIANO, C. A.; FERNÁNDEZ, H. H. Comportamiento ingestivo y consumo de bovinos en pastoreo. Revista Argentina de Produção Animal, Buenos Aires, v. 16, n. 2, p. 119-142, 1996.

GONTIJO NETO, M. M.; EUCLIDES, V. P. B.; NASCIMENTO JÚNIOR, D. Consumo e tempo diário de pastejo por novilhos Nelore em pastagem de capimtanzânia sob diferentes ofertas de forragem. Revista Brasileira de Zootecnia, Viçosa, MG, v. 35, n. 1, p. 6066, 2006.

HANCOCK, J. Grazing behaviour of cattle. Animal Breeding Abstract, Wallingford, v. 21, n. 1, p. 1-13, 1953.

HODGSON, J. Ingestive behavior. In: LEAVER, J. D. (Ed.). Herbage intake handbook. Hurley: British Grassland Society, 1982. 113 p.

The control of herbage intake in the grazing ruminant. Proceedings of the Nutrition Society, Cambridge, v. 40, n. 1, p. 339, 1985.

JAMIESON, W. S.; HODGSON, J. The effect of variation in sward characteristics upon the ingestive behavior and herbage intake of calves and lambs under continuous stocking management. Grass and Forage Science, Oxford, v. 34, n. 4, p. 273-281, 1979.

JOHNSON, A. D. Sample preparation and chemical analysis of vegetation. In: MANETJE, L. T. (Ed.). Measurement of grassland vegetation and animal production. Aberustwyth: Commonwealth Agricultural Bureaux, 1978. p. 96-102.

LACA, E. A., DEMMENT, M. W. Modelling intake of a grazing ruminant in a heterogeneous environment. In: INTERNATIONAL SYMPOSIUM ON VEGETATION HERBIVORE RELATIONSHIPS, 24., 1992, New York. Proceedings... New York: Academic Press, 1992. p. 5776.

MERTENS, D. R. Creating s system for meeting the fiber requirements of dairy cows. Journal of Dairy Science, Madison, v. 80, n. 7, p. 1463-1481, 1997.

Gravimetric determination of amylase-treated neutral detergent fiber in feeds with refluxing in beakers or crucibles: collaborative study. Journal of $A O A C$
International, Madison, v. 85, n. 6, p. 1217-1240, 2002.

MISSIO, R. L.; BRONDANI, I. L.; ALVES FILHO, D. C.; SILVEIRA, M. F.; FREITAS, L. S.; RESTLE, J. Comportamento ingestivo de tourinhos terminados em confinamento, alimentados com diferentes níveis de concentrado na dieta. Revista Brasileira de Zootecnia, Viçosa, MG, v. 39, n. 7, p. 1571-1578, 2010.

PARDO, R. M. P.; FISCHER, V.; BALBINOTTI, M.; ZANELA, M. B.; MORENO, C. B.; FERREIRA, E. X.; VINHAS, R. I.; MONKS, P. L. Comportamento ingestivo diurno de novilhos em pastejo a níveis crescentes de suplementação energética. Revista Brasileira de Zootecnia, Viçosa, MG, v. 32, n. 6, p. 1408-1418, 2003.

ROOK, A. J. Principles of foraging and grazing behavior. In: HOPKINS, A. (Ed.). Grass, its production and utilization. Edinburgh: Blackwell Science Ltda., 2000. p. 229-246.

SANTANA JÚNIOR, H. A.; SILVA, R. R.; CARVALHO, G. G. P.; SILVA, F. F.; BARROSO, D. S.; PINHEIRO, A. A.; ABREU FILHO, G.; CARDOSO, E. O.; DIAS, D. L. S.; TRINDADE JÚNIOR, G. Correlação entre desempenho e comportamento ingestivo de novilhas suplementadas a pasto. Semina: Ciências Agrárias, Londrina, v. 34, n. 1, p. 367-376, 2013.

SANTANA JÚNIOR, H. A.; SILVA, R. R.; CARVALHO, G. G. P.; SILVA, F. F.; MENDES, F. B. L.; ABREU FILHO, G.; TRINDADE JÚNIOR, G.; CARDOSO, E. O.; BARROSO, D. S.; PEREIRA, M. M. Correlação entre digestibilidade e comportamento ingestivo de novilhas suplementadas a pasto. Archivos de Zootecnia, Córdoba, v. 61, n. 236, p. 549-558, 2012.

SILVA, D. J.; QUEIROZ, A. C. Análise de alimentos: métodos químicos e biológicos. Viçosa: Universidade Federal de Viçosa, 2002. 235 p.

SILVA, R. R.; PRADO, I. N.; CARVALHO, G. G. P.; SANTANA JÚNIOR, H. A.; SILVA, F. F.; DIAS, D. L. S. Efeito da utilização de três intervalos de observações sobre a precisão dos resultados obtidos no estudo do comportamento ingestivo de vacas leiteiras em pastejo. Ciência Animal Brasileira, Goiânia, v. 9, n. 2, p. 319326, 2008.

SMITH, A. M.; REID, J. T. Use of chromic oxide as an indicator of fecal output for the purpose of determining the intake of a pasture herbage by grazing cows. Journal of Dairy Science, Madison, v. 38, n. 5, p. 515-524, 1955.

SNIFFEN, C. J.; O'CONNOR, J. D.; Van SOEST, P. J.; FOX, D. G.; RUSSELL, J. B. A net carbohydrate and protein system for evaluating cattle diets: IICarbohydrate and protein availability. Journal of Dairy Science, Madison, v. 70, n. 11, p. 3562-3577, 1992. 
STOBBS, T. H. The effect of plant structure on the intake of tropical pastures. I. Variation in the bite size of grazing cattle. Australian Journal of Agriculture Research, v. 24, n. 6, p. 809-819, 1973.

WEISS, W. P. Energy prediction equations for ruminant feeds. In: CORNELL NUTRITION CONFERENCE
FOR FEED MANUFACTURERS, 61., 1999, Ithaca. Proceedings... Ithaca: Cornell University, 1999. p. 176-185.

WILliANS, C. H.; DAVID, D. J.; LILMA, O. The determination of cromic oxide in feces samples by atomic absorption spectrophotometry. Journal of Agricultural Science, Cambridge, v. 59, n. 3, p. 381-385, 1962. 